\title{
Heterologous anti-progesterone monoclonal antibody arrests early embryonic development and implantation in the ferret (Mustela putorius)
}

\author{
V. Rider* and R. B. Heap \\ AFRC Institute of Animal Physiology, Babraham, Cambridge CB2 4AT, U.K.
}

\begin{abstract}
Summary. Early embryo development and implantation were arrested in ferrets passively immunized with a mouse monoclonal anti-progesterone antibody injected intraperitoneally at 72 and $96 \mathrm{~h}$ post coitum (p.c.) or at $72 \mathrm{~h}$ p.c. only. In control ferrets injected with mouse serum or $0.9 \% \mathrm{NaCl}$, implantation sites were found in all mated females; autopsies were carried out at Day 14 p.c. A total of 34 unimplanted embryos were recovered from the reproductive tract of antibody-treated ferrets and none of these had progressed to the blastocyst stage.

When ferrets were treated with antibody at $72 \mathrm{~h}$ p.c. and autopsies were carried out at Day 6 p.c., only 1 of 29 embryos recovered had progressed beyond the 4-cell stage in 4 females. In 4 control animals most embryos recovered at Day 6 were at the morula $(32 \%)$ or blastocyst $(28 \%)$ stage. Embryos from ferrets treated with antibody were therefore developmentally arrested when recovered $72 \mathrm{~h}$ after antibody administration.

Plasma progesterone concentrations were $\sim 6$-fold higher in antibody-treated ferrets with unimplanted embryos $(711 \pm 132 \mathrm{nmol} / \mathrm{l} ; 223 \mathrm{ng} / \mathrm{ml})$ compared with control pregnant females $(102 \pm 4 \mathrm{nmol} / 1 ; 32 \mathrm{ng} / \mathrm{ml})$ at Day 14 p.c. The results are consistent with the hypothesis that the normal course of pregnancy is arrested as a result of antibody binding of progesterone in the circulation, presumably causing a decrease in the amount of progesterone available to target cell receptors, and that heterologous anti-progesterone antibody blocks normal cleavage and embryonic development at an early stage before cavitation.
\end{abstract}

\section{Introduction}

Passive immunization with anti-progesterone monoclonal antibody at $32 \mathrm{~h}$ post coitum (p.c.) blocks normal early embryonic development (Wang, Rider, Heap \& Feinstein, 1984), prevents the initiation of implantation and reduces endometrial sensitivity in BALB/c mice (Rider, McRae, Heap \& Feinstein, 1985). The results suggest that a critical concentration of readily available progesterone is required soon after fertilization for embryonic development to proceed normally and subsequently for implantation to occur. It is important to establish whether this may also be true in animals of other species in which the sequence of events in early pregnancy differs substantially from that in the mouse, and for this purpose we elected to study the ferret. The initiation of implantation in the mouse occurs during the evening of Day 4 (Day 1, day of mating; Finn \& McLaren, 1967) whereas in the ferret a maternal pregnancy reaction is detectable from Day 7 onwards (Day 0 , day of mating; Gulamhusein \& Beck, 1977) and blastocysts begin to implant on Day 12 (Enders \& Schlafke, 1972). Corpora lutea in the pseudopregnant mouse have a shorter life-span than during pregnancy (Deanesly, 1930) whereas in the ferret their functional life is similar to that in normal

* Present address: Department of Cell Biology, Baylor College of Medicine, Texas Medical Center, Houston, Texas 77030, U.S.A. 
pregnancy (Hammond \& Marshall, 1930; Heap \& Hammond, 1974). Maintenance of decidual and stromal cells in the uterus of the mouse depends on continual progesterone secretion since cessation of secretion results in the demise of these cells (Finn, 1982), whereas in the ferret the maternal pregnancy reaction is adeciduate (Beck, 1974) and the endometrium of ferrets ovariectomized at Day 4 p.c. continues to differentiate in the absence of ovarian steroids (Buchanan, 1969). This latter finding suggests that once the endometrium is stimulated by ovarian hormones it is capable of prolonged response without further stimulus. These differences between the two species indicate that the ferret is an appropriate animal in which to test the importance of maternal progesterone during the early stages of embryonic development. In addition, this study may provide a basis for an interceptive treatment that would be effective in other carnivores, such as the dog or cat.

\section{Materials and Methods}

Animals. Adult female ferrets previously kept in a short daylength were housed in a $4 \cdot 0 \mathrm{~m}^{2}$ pen under a lighting regimen of $18 \mathrm{~h}$ light and $6 \mathrm{~h}$ dark. Early weaner pig pellets (C. Hitchcock Ltd, Bures, Suffolk) and water were freely available. Two adult males were kept in individual cages in an adjacent room under a reversed lighting schedule $(6 \mathrm{~h}$ light: $18 \mathrm{~h}$ dark $)$. Oestrus was determined by vulval enlargement and when this had reached its maximum they were mated with a fertile male at 10:00-12:00 h (Day 0). The next day females were placed with a different fertile male (Day 1) and then returned to the colony at Day 2.

Monoclonal antibody. Ascites fluid containing anti-progesterone monoclonal antibody (DB3) was produced and characterized as $\operatorname{IgG}_{1}$ by the methods previously described (Wright et al., 1982). Ascites fluid from cloned DB3 cells was lyophilized, reconstituted with distilled water, divided into $2.5 \mathrm{ml}$ aliquants and stored at $-60^{\circ} \mathrm{C}$. The immunoglobulin concentration (pool $1,155 \mathrm{nmol}$ $\mathrm{IgG} / \mathrm{ml}, 154.9 \mathrm{mg}$ total protein $/ \mathrm{ml}$; pool $2,133 \mathrm{nmol} \mathrm{IgG} / \mathrm{ml}, 132.9 \mathrm{mg}$ total protein $/ \mathrm{ml}$ ) was determined in a Beckman Model E analytical ultracentrifuge equipped with Schlieren optics by comparison with a known concentration of IgG. Progesterone binding of the ascites fluid pools was tested after serial dilution in sodium phosphate buffer $(0.05 \mathrm{~mol} / \mathrm{l}), \mathrm{pH} 7.4$ (1:2000 up to 1:32 000) by a radioligand binding assay as previously described (Wright et al., 1982). A volume of $100 \mu 1$ ascites fluid $(15.5 \mathrm{nmol})$ when diluted approximately $1: 17000$ bound $50 \%$ of a known quantity of $\left[{ }^{3} \mathrm{H}\right]$ progesterone (135 $\left.\mathrm{Bq}, 0.08 \mathrm{pmol}\right)$.

Anti-fertility test. Mated females were assigned to one of 4 groups and treated at 10:00-12:00 h. Group 1 received an intraperitoneal (i.p.) injection of $2 \mathrm{ml}$ antibody (54.0 $\mathrm{mg}$ anti-progesterone $\mathrm{IgG} / \mathrm{kg}$ body weight) at $72 \mathrm{~h}$ and $96 \mathrm{~h}$ after the first insemination (Day 0). Group 2 was injected with $2 \mathrm{ml}$ antibody containing $54.0 \mathrm{mg}$ anti-progesterone $\mathrm{IgG} / \mathrm{kg}$ at $72 \mathrm{~h}$ p.c. only. Control females were injected at $72 \mathrm{~h}$ and $96 \mathrm{~h}$ p.c. with $2 \mathrm{ml}$ volume of normal BALB/c mouse serum (Group 3) that had been lyophilized and concentrated $(153.1 \mathrm{mg}$ total protein $/ \mathrm{ml})$ in a similar manner to ascites fluid, or $2 \mathrm{ml} 0.9 \%(\mathrm{w} / \mathrm{v}) \mathrm{NaCl}$ (Group 4). In the mouse, pregnancy rates were normal when females were treated with equivalent amounts of mouse serum, purified $\mathrm{IgG}_{1}$ produced by a plasmacytoma (MOPC 21) or ascites fluid obtained from a mouse myeloma (MoPC 1748). These control samples showed a binding of $\left[{ }^{3} \mathrm{H}\right]$ progesterone which was less than $1 \%$ when diluted $1: 1000$.

Pseudopregnancy was induced in unmated females in oestrus by subcutaneous injection of 50 i.u. human chorionic gonadotrophin (hCG) (Intervet, Cambridge) (Day 0).

Autopsies were carried out at Day 14 of pregnancy or pseudopregnancy. Blood was collected by cardiac puncture under ether anaesthesia. The ovaries and reproductive tract were removed and the number of corpora lutea and implantation sites were recorded. In females showing no evidence of implanted embryos the oviducts and uterine horns were flushed with phosphate-buffered saline (PBS), $\mathrm{pH} \mathrm{7.4,} \mathrm{to} \mathrm{recover} \mathrm{unimplanted} \mathrm{embryos.} \mathrm{Uterine} \mathrm{horns} \mathrm{and} \mathrm{ovaries} \mathrm{were} \mathrm{fixed} \mathrm{in} 10 \%(\mathrm{v} / \mathrm{v})$ formal-saline or Bouin's fixative, processed for histological examination and stained with haematoxylin and eosin (H and E) or by periodic acid-Schiff (PAS). 
Effect of antibody treatment on the early embryo. Mated females were injected i.p. with DB3 anti-progesterone antibody $(54.0 \mathrm{mg} \mathrm{IgG/} / \mathrm{kg})$ or an equivalent volume of $0.9 \%(\mathrm{w} / \mathrm{v}) \mathrm{NaCl}$ at $72 \mathrm{~h}$ p.c. At Day 6 p.c., the oviducts and uterine horns were flushed with PBS to recover unimplanted embryos. Hyaluronidase (Sigma Chemical Co. Ltd, Poole, Dorset) was added to the PBS collection medium to facilitate removal of cumulus granulosa cells. Denuded (cumulus-free) embryos and eggs were air-dried (Tarkowski, 1966), stained with Giemsa and the number of nuclei were counted. Eggs were scored as unfertilized when metaphase II chromosomes were identified.

Plasma progesterone. Plasma was separated by centrifugation at $4^{\circ} \mathrm{C}$ and stored at $-20^{\circ} \mathrm{C}$ until assayed. Plasma samples were thawed at room temperature, diluted 40 - to 200 -fold with sodium phosphate buffer $(0.05 \mathrm{~mol} / \mathrm{l}), \mathrm{pH} 7.4$, and $100 \mu$ l portions were extracted in duplicate with $5.0 \mathrm{ml}$ diethyl ether. After shaking for $10 \mathrm{~min}$, the ether phase was decanted and evaporated to dryness under a stream of nitrogen at $40^{\circ} \mathrm{C}$. The extract was analysed by radioimmunoassay according to the method described by Ricketts, Galil, Ackland, Heap \& Flint (1980). A polyclonal antiserum (18/3, kindly supplied by Dr A. P. F. Flint of this Institute) which was raised in sheep against $11 \alpha$-hemisuccinyl-bovine serum albumin was used at a dilution of 1:6000. Its specificity has previously been reported (Sheldrick, Mitchell \& Flint, 1980). The recovery of $\left[{ }^{3} \mathrm{H}\right]$ progesterone added to plasma was $96.0 \pm 0.7 \%$ (mean \pm s.e.m., 9 observations), and the sensitivity of the assay was $0.10 \pm 0.02 \mathrm{pmol} /$ assay tube (calculated from $2 \times$ s.d. below the value at zero concentration). The intra-assay coefficient of variation was $17.7 \%$ and the inter-assay coefficients of variation were $18.9 \%(3.2 \mathrm{pmol}$ progesterone $/ \mathrm{ml})$ and $13.9 \%(6.4 \mathrm{pmol}$ progesterone $/ \mathrm{ml})$. Adding $3.2 \mathrm{pmol} / \mathrm{ml}$ and $6.4 \mathrm{pmol} / \mathrm{ml}$ progesterone to $1.0 \mathrm{ml}$ plasma from an anoestrous ferret gave values of $3 \cdot 0 \pm 0 \cdot 2 \mathrm{pmol} / \mathrm{ml}$ and $5 \cdot 7 \pm 0 \cdot 3 \mathrm{pmol} / \mathrm{ml}$ ( 9 observations).

Statistical analysis. The experimental results are given as means \pm s.e.m. Mean differences between groups were considered to be significant if the appropriate test gave a $P$ value of $<0.05$. Differences between means were determined by Student's $t$ test or Bayesian methods on a difference between two proportions (Walters, 1985).

\section{Results}

\section{Passive immunization with mouse anti-progesterone antibody arrests implantation}

Mouse anti-progesterone monoclonal antibody arrested implantation in 5 of 6 mated females injected intraperitoneally at 72 and $96 \mathrm{~h} p . c$., and in 3 of 3 mated females injected at $72 \mathrm{~h} p . c$. only (Table 1). The single female with implanted embryos after antibody treatment had a normal number of implantation sites, but local swellings at the injection site suggested that antibody had probably been administered subcutaneously rather than intraperitoneally. Mouse serum containing a similar concentration of total protein as antibody did not affect fertility, nor did an injection of an equal volume of $0.9 \mathrm{NaCl}$ (Table 1). The mean number of implantation sites in females treated with mouse serum $(9 \cdot 0 \pm 1 \cdot 4)$ was comparable with that found in saline-treated animals $(11 \cdot 8 \pm 1 \cdot 2)$.

\section{Embryo development arrested after antibody treatment}

A total of 42 embryos were recovered from the reproductive tract of 9 antibody-treated ferrets at Day 14 p.c. (Table 1). Some embryos $(6,14 \%)$ were retained in the oviduct after passive immunization, while most $(28,66 \%)$ were recovered from the uterus at Day 14 p.c. Of the 42 embryos recovered at Day 14, $34(81 \%)$ were unimplanted and had not progressed to the blastocyst stage regardless of their location (Table 1). Each unimplanted embryo was still surrounded by its zona pellucida and in some females by endometrial secretions. Eight $(19 \%)$ normal implantation sites based on macroscopic examination occurred in one female. 


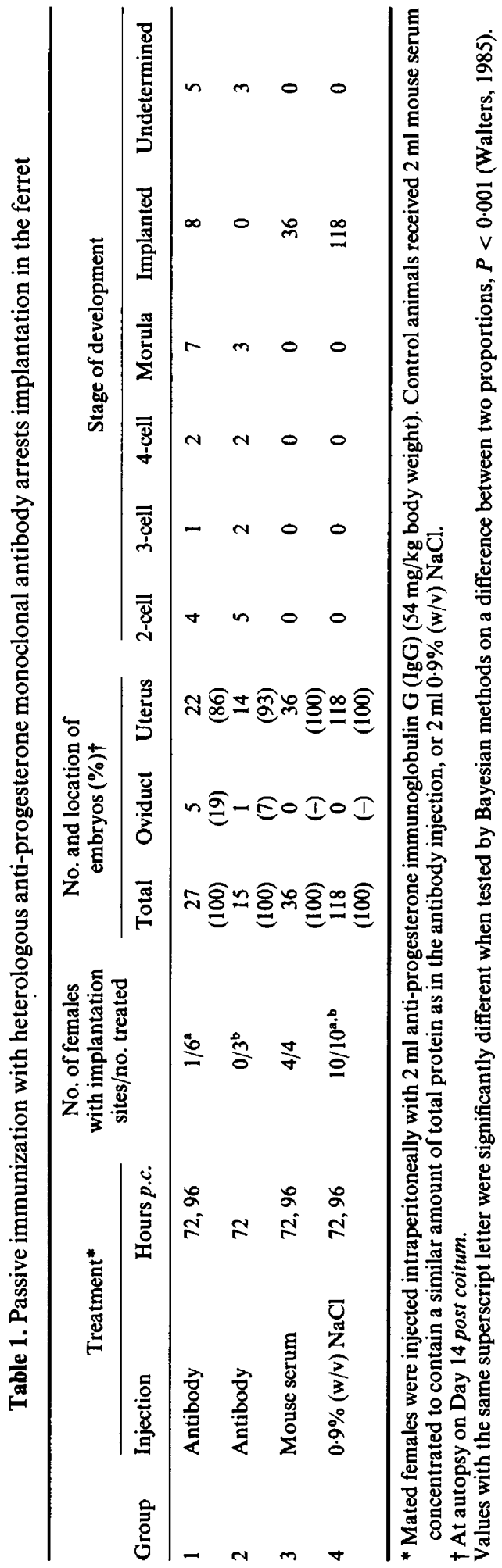




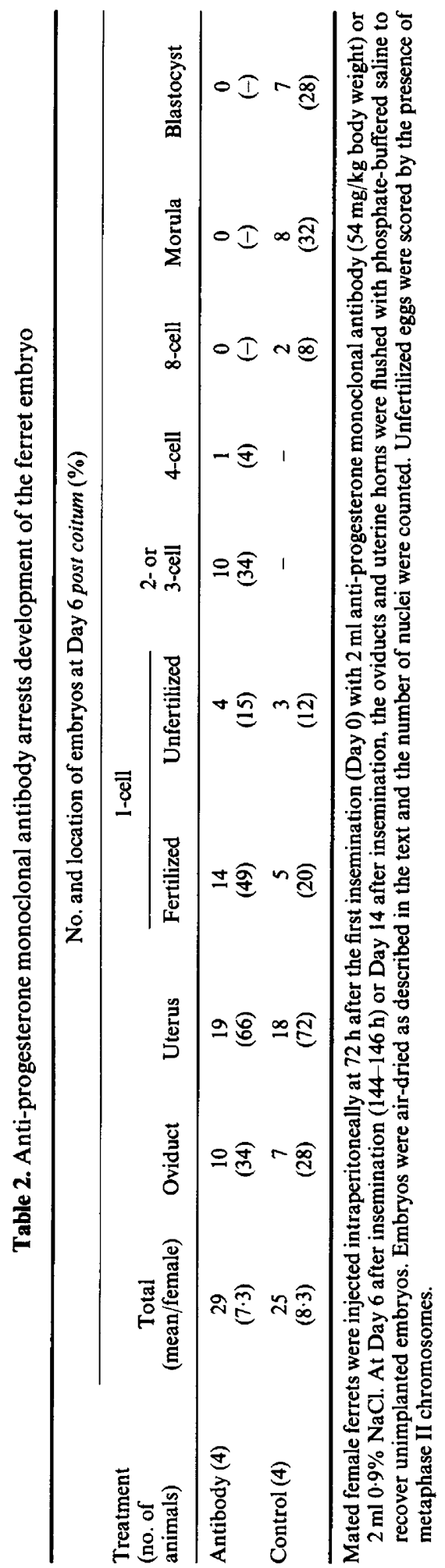




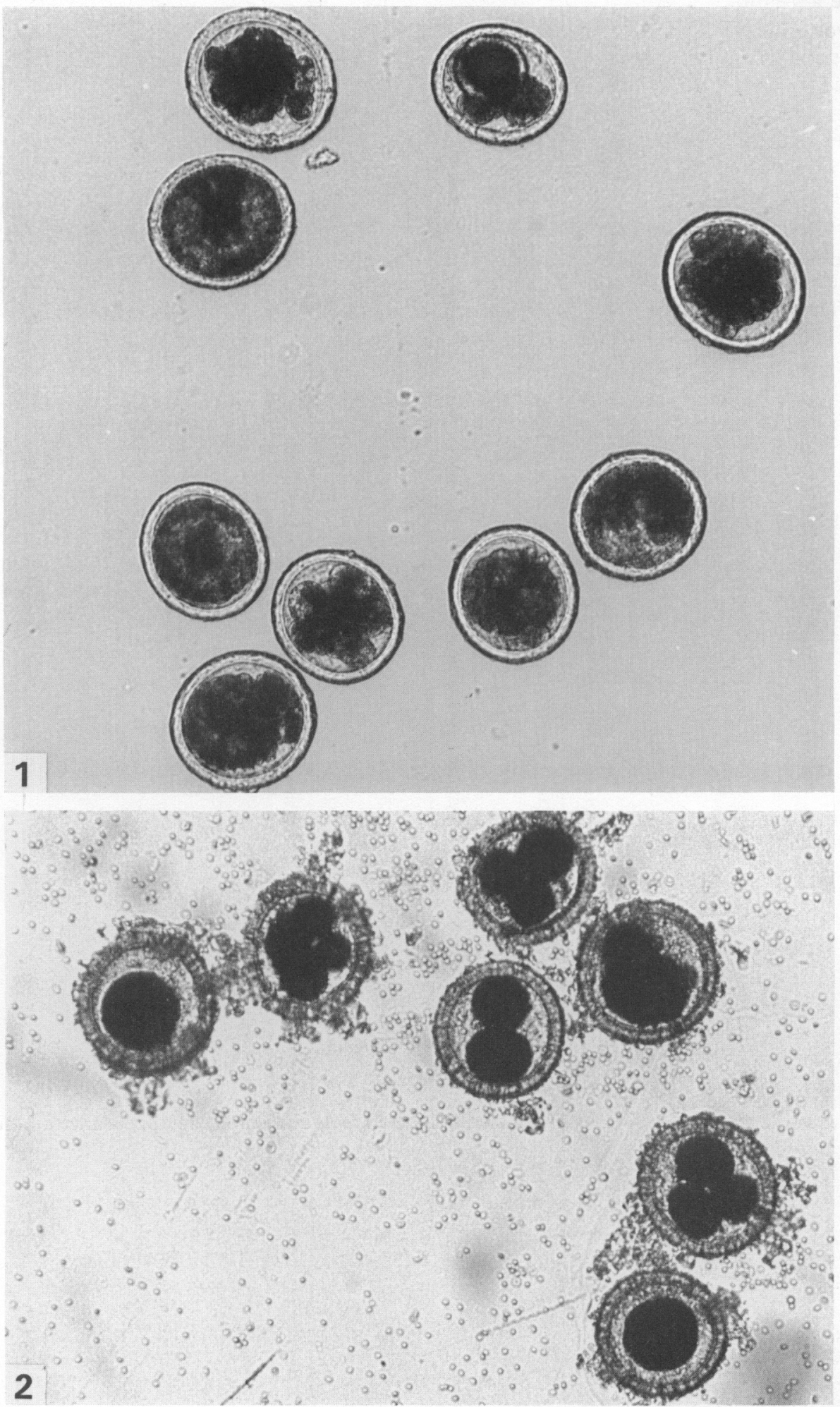


The appearance of embryos recovered at Day 6 p.c. was different from that at Day 14 p.c. Embryos from antibody-treated females were surrounded by a zona pellucida, as in control females, and in some cases cumulus granulosa cells. At this earlier time, however, embryos were not enclosed by endometrial secretions and the adherent granulosa cells were loosely attached since they were easily removed by addition of hyaluronidase to the collection medium. The number of embryos recovered after antibody treatment $(29,7 \cdot 3$ per female) was similar to that in control females $(25,8.3$ per female). In both groups some embryos were found in the oviduct (control females, $28 \%$; treated females, $34 \%$ ) while most were located in the uterus (Table 2).

Embryos from ferrets treated with anti-progesterone monoclonal antibody were developmentally arrested at Day 6 (Figs $1 \& 2$; Table 2). Of 29 embryos recovered, only one had progressed to the 4-cell stage. In control females most embryos were at the morula $(32 \%)$ or blastocyst $(28 \%)$ stage. The number of eggs containing chromosomes at metaphase II, and thus unfertilized, was similar in females of both groups (15 vs $12 \%)$.

\section{Effect of monoclonal antibody on plasma progesterone concentrations}

Plasma progesterone concentrations in cardiac blood were about 4- to 6-fold greater in females treated with anti-progesterone antibody (Groups 1 and 2) than in control pregnant females (Groups 3 and 4, Table 3). The concentration of progesterone in plasma of the female with implanted embryos after antibody-treatment was similar to that of non-pregnant treated females (Group 1, Table 3).

Table 3. Plasma progesterone concentrations in ferrets after passive immunization with heterologous anti-progesterone monoclonal antibody (see Table 1 for details of treatment)

\begin{tabular}{cllcrc}
\hline & & \multicolumn{4}{c}{ Plasma progesterone conc. (nmol/l) $\dagger$} \\
\cline { 3 - 6 } Group & \multicolumn{1}{c}{$\begin{array}{c}\text { Treatment } \\
\text { (no. of animals) }\end{array}$} & & \multicolumn{2}{c}{$\begin{array}{c}\text { Pregnant } \\
\text { (implanted) }\end{array}$} & Non-implanted \\
\hline 1 & Antibody & $(6)$ & $616 \cdot 6$ & $(1)$ & $711 \cdot 0 \pm 132 \cdot 3(5)$ \\
2 & Antibody & $(3)$ & - & & $469 \cdot 3 \pm 31 \cdot 8(3)$ \\
3 & Mouse serum & $(4)$ & $98 \cdot 6 \pm 10 \cdot 4$ & $(4)$ & - \\
4 & $0 \cdot 9 \%(\mathbf{w} / \mathrm{v}) \mathrm{NaCl}$ & $(10)$ & $102 \cdot 4 \pm 3 \cdot 8$ & $(10)$ & - \\
\hline
\end{tabular}

† At autopsy on Day 14 post coitum.

Mean plasma progesterone concentrations were slightly higher in pseudopregnant $(123.4 \pm 4.0 \mathrm{nmol} / 1 ; 38.6 \mathrm{ng} / \mathrm{ml})$ compared with pregnant control females $(102.4 \pm 3.8 \mathrm{nmol} / \mathrm{l}$; $32.2 \mathrm{ng} / \mathrm{ml}$ ) due to an increased number of corpora lutea produced by hCG injection.

Prominent corpora lutea were present in females of all groups at the time of autopsy. The luteal cells were large, they contained well-developed nuclei and their microscopic appearance was similar among the different groups (Figs $3 \& 4$ ). Interstitial tissue was also similar in appearance among the different groups.

Fig. 1. In control ferrets, most of the embryos were at the morula or blastocyst stage of development by Day 6 . After the 8-cell stage cumulus cells were not observed surrounding the embryo. $\times 115$.

Fig. 2. Representative example of embryos flushed from the reproductive tract of an antibody-treated ferret. None of the embryos recovered at Day 6 post coitum had progressed beyond the 4-cell stage. Cumulus granulosa cells, as shown by light microscopy, were easily removed from fertilized eggs with hyaluronidase. $\times 115$. 

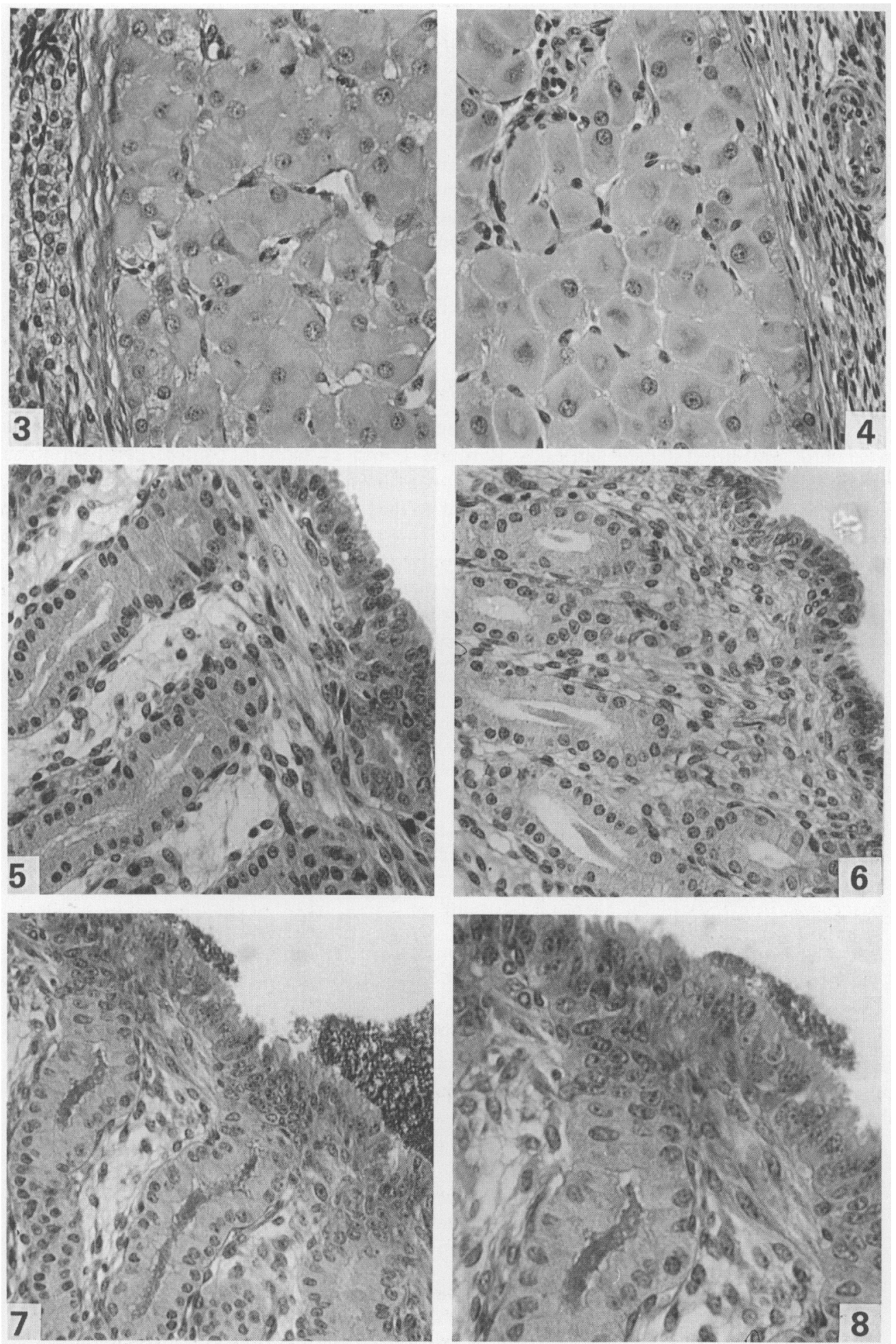


\section{Morphological appearance of the antibody-treated uterus}

The endometrium of ferrets treated with antibody appeared similar at Day 14 p.c. to that of the preimplantation endometrium reported by Buchanan (1966), and to that of pseudopregnant control ferrets in the present study (Figs 5-8). The uterine epithelium was pseudostratified, endometrial glands were numerous and well developed, and were dilated with deposits of PAS-positive material both within the glands and along the surface of the luminal epithelium (Figs $7 \& 8$ ).

\section{Discussion}

A single injection of heterologous monoclonal antibody against progesterone arrested implantation in the ferret. Our findings also show that immunization arrests normal embryonic development in the ferret, as in the mouse (Wang et al., 1984), and this probably results from an interference with the availability of circulating progesterone for target cell interaction.

In the present study, the concentration of progesterone in the plasma of normal pregnant females at Day 14 p.c. was similar to that previously reported (Heap \& Hammond, 1974; Daniel; 1976). Plasma progesterone concentrations in antibody-treated ferrets, however, were 4- to 6-fold higher than those for pregnant control females injected with saline or an equal quantity of mouse serum proteins. A similar increase in plasma progesterone occurs in mice after antibody treatment (Wang et al., 1984), and yet an important difference between the two species exists. Corpora lutea in antibody-treated mice have started to regress by Day 10 p.c. (Wright et al., 1982) while those in the ferret are morphologically similar to corpora lutea in control (pregnant and pseudopregnant) animals at Day 14. Plasma progesterone concentrations during normal pregnancy reach very similar maximum values in the two species (Heap \& Hammond, 1974; McCormick \& Greenwald,

Fig. 3. Light microscopy of a typical corpus luteum in the ovary of a pseudopregnant ferret at Day 14 after hCG treatment. The luteal cells were large and contained prominent nuclei. Corpora lutea in all treatment groups were similar in number and histological appearance. $\mathrm{H} \& \mathrm{E}$, $\times 270$.

Fig. 4. A representative example of the histological appearance of a corpus luteum at Day 14 post coitum from the ovary of a ferret treated with anti-progesterone monoclonal antibody. The morphological appearance was similar to that of pseudopregnant control females (Fig. 3). H \& E, $\times 270$.

Fig. 5. Endometrium of a pseudopregnant ferret 14 days after hCG treatment to induce pseudopregnancy. The uterine glands are prominent and the glandular and luminal epithelial cells are well-developed. $\mathrm{H} \& \mathrm{E}, \times 300$.

Fig. 6. The endometrium of an antibody-treated ferret at Day 14 p.c. Glandular development, including elongation, was similar to that seen in pseudopregnant females at a similar time after ovulation. $\mathrm{H} \& \mathrm{E}, \times 270$.

Fig. 7. Deposits of PAS-positive material after diastase extraction were present in the uterine glands and along the luminal epithelium of the pseudopregnant endometrium. The uterine lumen also contained large amounts of PAS-positive material. PAS, $\times 420$.

Fig. 8. The amount of PAS-positive diastase resistant material in the uterine glands of antibody-treated ferrets was similar to that observed in pseudopregnant animals. PAS-positive material was also present along the luminal epithelium and uterine lumen although the amount in the lumen appeared to be reduced in antibody-treated ferrets. PAS, $\times 560$. 
1974; Gerber, Jacquet, Léonard \& Maes, 1979), so that the much higher values found after antibody treatment in the ferret must be associated with sustained luteal function in the presence of circulating antibody. Heterologous 7S gamma globulin has a half-life of about 4-6 days (Spiegelberg \& Weigle, 1965). The high progesterone values are not related to treatment with heterologous proteins since the concentration of progesterone in plasma of control ferrets treated with a comparable quantity of mouse serum proteins was similar to that in control animals treated with saline. This finding, and the fact that there is a 4- to 6-fold increase in plasma progesterone after passive immunization, suggests that in the ferret, as in the mouse, the arrest of implantation is associated with the binding of maternal progesterone in circulation by antibody which results in a reduction in the amount of progesterone available to target cell receptors during early pregnancy.

Antibody-induced developmental arrest was associated with a block in early cleavage rather than fertilization failure since the number of unfertilized eggs was similar between antibody-treated and control animals. None of the unimplanted ferret embryos from antibody-treated females had developed into normal expanded blastocysts when recovered at Days 6 or 14 p.c., and in the latter instance they failed to initiate a normal implantation reaction at the expected time. It is important to consider the time at which arrest was initiated since this would indicate whether the antibody affected the normal process of cleavage immediately or after a more prolonged period of action. We found that $81 \%$ of embryos were arrested before they reached the 4-cell stage when ferrets were injected at $72 \mathrm{~h}$ p.c. and examined at Day 6 p.c., and the same percentage showed delayed development at Day 14 p.c. although cell division had progressed slowly since 10 of 34 embryos had reached the morula stage. Robinson (1918) and Hamilton (1934) observed that the ferret embryo has normally developed to the $4-8$ cell stage by $72 \mathrm{~h}$ after insemination, though they occasionally are 2-cell or 10-cell at this time, reflecting the considerable range of developmental stages found in early embryonic life. Therefore, it seems that the antibody effect on embryo development occurs rapidly after injection, producing a sharp and almost immediate reduction in the rate of cleavage rather than a complete inhibition of cell division or embryotoxicity.

The results raise the question of how antibody treatment induces embryo arrest. One possibility that must be considered is whether the antibody itself or high local concentrations of antibody-bound progesterone have a direct effect on the early embryo. Whitten (1957) reported a toxic and inhibitory effect of progesterone on the development of 8-cell mouse embryos into blastocysts in vitro when the steroid was added at a concentration greater than $12 \cdot 7 \mu \mathrm{mol} / 1(4 \mu \mathrm{g} / \mathrm{ml})$. Similar findings were obtained by Kirkpatrick (1971) with mouse eggs cultured from the 2-cell stage, and by Daniel (1964) and Daniel \& Levy (1964) with rabbit eggs cultured from the 1-cell stage, but in all these studies the concentration of progesterone required was extremely high $(25 \mathrm{nmol} / 1$ and $32 \mu \mathrm{mol} / 1$, respectively). We do not know whether the concentration of progesterone in the vicinity of the early ferret embryo reaches these levels after passive immunization or whether antibody gains access to the luminal environment in a sufficient amount to produce such an effect. However, preliminary studies with 2-cell mouse embryos show that the addition of purified anti-progesterone monoclonal IgG (up to $7 \cdot 3 \mu \mathrm{mol} / \mathrm{l}$ ) saturated with progesterone $(15 \mu \mathrm{mol} / \mathrm{l})$ fails to affect the rate of blastocyst formation in vitro (V. Rider, unpublished observations). The present results also show that tubal transport in the ferret was probably not seriously affected by passive immunization since the proportion of embryos in the uterus and oviduct was similar in antibody-treated animals to that in control animals at Day 6 p.c. (Table 2). The available evidence so far supports the hypothesis that passive immunization in early pregnancy causes an arrest of embryo development indirectly, the antibody preventing progesterone from reaching target cell receptors which results in a tubal environment incompatible with normal cleavage.

The importance of maternal progesterone during tubal development of the embryo in vivo has not been investigated previously in this species. Earlier studies in the ferret suggested deleterious effects of ovarian steroid removal on the blastocyst rather than on the pre-cavitation embryo. Buchanan (1969) found that ovariectomy at Day 4 prevented expansion of ferret blastocysts and subsequent implantation, although unexpanded blastocysts survived until Day 15 p.c. without 
signs of degeneration. Steroid treatment improved the morphological appearance of blastocysts in ferrets ovariectomized at Day 6 p.c. but implantation failed to occur at the normal time (Wu \& Chang, 1972). Our results suggest that the ferret embryo is susceptible to a reduction in available maternal progesterone during very early cleavage, and this finding is consistent with that obtained in the mouse.

It is probable that the antibody also exerts an antifertility effect by reducing the sensitivity of the endometrium to the presence of the blastocyst (Rider et al., 1985). The histological appearance of the endometrium in passively immunized animals showed evidence of progesterone stimulation in support of the suggestion of Buchanan (1969) that the ferret endometrium is capable of prolonged response once stimulated by ovarian hormones. However, several investigators have shown that, although the endometrium continues to differentiate after steroid removal, it fails to support the development and normal implantation of blastocysts in ferrets ovariectomized before Day 10 p.c. (Buchanan, 1969; Wu \& Chang, 1972, 1973; Foresman \& Mead, 1978). Implantation will occur at the normal time (Day 13 p.c.) if ovariectomized ferrets are treated with progesterone alone or combined with oestradiol-17 (Wu \& Chang 1973), and it has been suggested that there is another ovarian hormone secreted before Day 8 p.c. which acts in conjunction with progesterone to induce nidation (Foresman \& Mead, 1978; Mead \& McRae, 1982). It is notable that in several of these studies implantation was delayed by ovariectomy and it seems that ferret blastocysts can withstand a 7-day period of experimentally-induced delay of implantation without loss of viability (Foresman \& Mead, 1978).

Our results indicate that since neutralization of progesterone by passive immunization with a monoclonal antibody arrests implantation in the ferret, such a procedure may provide a new and useful approach to the interception of pregnancy in other carnivores such as the dog and cat. Further work is required to demonstrate how long embryos will survive after antibody-induced developmental arrest and whether delayed implantation will eventually occur even in the absence of exogenous progesterone administration.

We thank Mr J. Hammond Jr for expert help and advice; the referees of this paper who made valuable suggestions; Mr A. Woodley and Mrs E. M. Tredgett for technical assistance; Mr D. E. Walters, AFRC Statistics Group, Cambridge, for statistical analysis; Dr A. Whyte and Dr R. Popkin for helpful comments; and Mrs J. Tickner for typing the manuscript. V.R. received financial support from Johnson and Johnson and the Lalor Foundation.

\section{References}

Beck, F. (1974) The development of a maternal pregnancy reaction in the ferret. $J$. Reprod. Fert. 40, $61-69$.

Buchanan, D.G. (1966) Reproduction in the ferret (Mustela furo). I. Uterine histology and histochemistry during pregnancy and pseudopregnancy. Am. J. Anat. 118, 195-216.

Buchanan, D.G. (1969) Reproduction in the ferret (Mustela furo). II. Changes following ovariectomy during early pregnancy. J. Reprod. Fert. 18, 305-316.

Daniel, J.C. (1964) Some effects of steroid on cleavage of rabbit eggs in vitro. Endocrinology 75, 706-710.

Daniel, J.C., Jr (1976) Plasma progesterone levels before and at the time of implantation in the ferret. $J$. Reprod. Fert. 48, 437-438.

Daniel, J.C. \& Levy, J.D. (1964) Action of progesterone as a cleavage inhibitor of rabbit ova in vitro. $J$. Reprod. Fert. 7, 323-329.

Deanesly, R. (1930) The corpora lutea of the mouse, with special reference to fat accumulation during the oestrous cycle. Proc. R. Soc. B. 106, 578-595.

Enders, A.C. \& Schlafke, S. (1972) Implantation in the ferret; epithelial penetration. Am. J. Anat. 133, 291-316.

Finn, C.A. (1982) Cellular changes in the uterus during the establishment of pregnancy in rodents. $J$. Reprod. Fert., Suppl. 31, 105-111.

Finn, C.A. \& McLaren, A. (1967) A study of the early stages of implantation in mice. J. Reprod. Fert. 13, 259-267.

Foresman, K.R. \& Mead, R.A. (1978) Luteal control of nidation in the ferret (Mustela putorius). Biol. Reprod. 18, 490-496.

Gerber, G.B., Jacquet, P., Léonard, A. \& Maes, J. (1979) Evolution des taux d'oestradiol, de progésterone et de prostaglandines $E$ et $F_{2 a}$ durant la gestation chez la souris. C. r. Séanc. Soc. Biol. 173, 644-649.

Gulamhusein, A.P. \& Beck, F. (1977) Determination of a 
sensitive period for the induction of the maternal pregnancy reaction in the ferret. J. Reprod. Fert. 49, 127-128.

Hamilton, W.J. (1934) The early stages in the development of the ferret: fertilisation to the formation of the prochordal plate. Trans. R. Soc. Edinb. 58, 251-278.

Hammond, J. \& Marshall, F.H.A. (1930) Oestrus and pseudopregnancy in the ferret. Proc. $R$. Soc. $B \mathbf{1 0 5}$, $607-629$.

Heap, R.B. \& Hammond, J., Jr (1974) Plasma progesterone levels in pregnant and pseudopregnant ferrets. J. Reprod. Fert. 39, 149-152.

Kirkpatrick, J.F. (1971) Differential sensitivity of preimplantation mouse embryos in vitro to oestradiol and progesterone. J. Reprod. Fert. 27, 283-285.

Mead, R.A. \& McRae, M. (1982) Is estrogen required for implantation in the ferret? Biol. Reprod. 27, 540-547.

McCormick, J.T. \& Greenwald, G.S. (1974) Progesterone and oestradiol- $17 \beta$ concentrations in the peripheral plasma during pregnancy in the mouse. J. Endocr. 62, 101-107.

Ricketts, A.P., Galil, A.K.A., Ackland, N., Heap, R.B. \& Flint, A.P.F. (1980) Activation by corticosteroids of steroid metabolizing enzymes in ovine placental explants in vitro. J. Endocr. 85, 457-469.

Rider, V., McRae, A., Heap, R.B. \& Feinstein, A. (1985) Passive immunization against progesterone inhibits endometrial sensitization in pseudopregnant mice and has antifertility effects in pregnant mice which are reversible by steroid treatment. $J$. Endocr. 104, 153-158.

Robinson, A. (1918) The formation, rupture, and closure of ovarian follicles in ferrets and ferret-polecat hybrids, and some associated phenomena. Trans. $R$. Soc. Edinb. 52, 303-362.
Sheldrick, E.L., Mitchell, M.D. \& Flint, A.P.F. (1980) Delayed luteal regression in ewes immunized against oxytocin. J. Reprod. Fert. 59, 37-42.

Spiegelberg, H.L. \& Weigle, W.O. (1965) The catabolism of homologous and heterologous $7 \mathrm{~S}$ gamma globulin fragments. J. exp. Med. 121, 323-338.

Tarkowski, A.K. (1966) An air drying method for chromosome preparations from mouse eggs. Cytogenetics 5, $394-400$.

Walters, D.E. (1985) On the reliability of Bayesian confidence limits for a difference of two proportions. Biometrical $J$. (in press).

Wang, M.-Y., Rider, V., Heap, R.B. \& Feinstein, A. (1984) Action of anti-progesterone monoclonal antibody in blocking pregnancy after postcoital administration in mice. $J$. Endocr. 101, 95-100.

Whitten, W.K. (1957) The effect of progesterone on the development of mouse eggs in vitro. J. Endocr. 16, 80-85.

Wright, L.J., Feinstein, A., Heap, R.B., Saunders, J.C., Bennett, R.C. \& Wang, M.-Y. (1982) Progesterone monoclonal antibody blocks implantation in mice. Nature, Lond. 295, 415-417.

Wu, J.T. \& Chang, M.C. (1972) Effects of progesterone and estrogen on the fate of blastocysts in ovariectomized pregnant ferrets: a preliminary study. Biol. Reprod. 7, 231-237.

Wu, J.T. \& Chang, M.C. (1973) Hormonal requirements for implantation and embryonic development in the ferret. Biol. Reprod. 9, 350-355.

Received 26 June 1985 